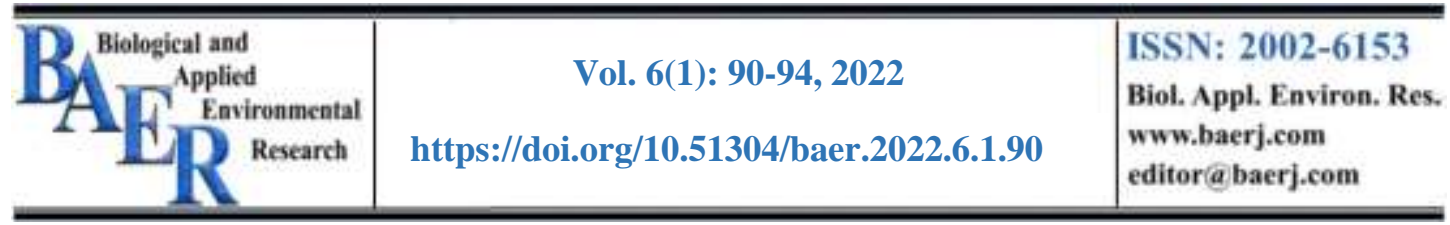

\title{
First Record of the Nemaode Pseudocapillaria tomentosa (Dujardin, 1845) Moravec, 1987 in Cultured Grass Carp in Basrah Province, Iraq
}

\author{
Abdul Amer R. Jassim ${ }^{1 *}$, Nadirah K. Al-Salim² \& Najim R. Khamees ${ }^{2}$ \\ ${ }^{1}$ Marine Science Centre, University of Basrah, Iraq \\ ${ }^{2}$ Department of Fisheries and Marine Resources, College of Agriculture, \\ University of Basrah, Iraq \\ *Corresponding author: abdulamer.jassim@uobasrah.edu.iq

\begin{abstract}
A total of 110 specimens of cultured grass carp Ctenopharyngodon idella (Pisces: Cyprinidae) were collected from three different fish pond stations in Basrah province, during the period from March till July 2007. Postmortem parasitological examinations indicated infection of the grass carp with the nematode Pseudocapillaria tomentosa and this infection occurred only in Faddak fish ponds during all months of investigation. The maximum incidence of infection was $26.6 \%$ in April, while the maximum intensity of infection was 8.5 in June. The present finding of this nematodes represents its first record in Iraqi fishes.
\end{abstract}

Keywords: Nematoda, Capillariidae, Pseudocapillaria tomentosa, Grass carp, Fish ponds, Basrah province

\section{Introduction}

Capillarids infect vertebrates, and are often pathogenic due to their invasive nature (Moravec, 1987). According to GBIF (2021), Pseudocapillaria tomentosa (Dujardin, 1845) Moravec, 1987 has 13 synonyms which included Capillaria amurensis Finogenova, 1967; C. bakeri Mueller et Van Cleave, 1932; C. catostomi Pearse, 1924; C. gobionina Lomakin, 1971; C. leucisci Hesse, 1923; C. lewaschoffi Heinze, 1993; C. pseudorasborae Wang, Zhao et Chen, 1978; C. rutili Zakhvatkin \& Azheganova, 1940; C. ugui Yamaguti, 1941; Skrjabinocapillaria elopichthydis Wang, 1982; Trichosoma brevispiculum Linstow, 1873; T. cyprini Diesing, 1851 and T. tomentosum Dujardin, 1843. P. tomentosa has a broad host specificity, infecting some 25 cyprinid fish species and members of other orders such as Anguilliformes, Gadiformes, Salmoniformes and Siluriformes (Moravec, 1987).

According to GBIF (2021) and WoRMS (2021), P. tomentosa belongs to the family Capillariidae, Order Trichinellida, class Enoplea of the phylum Nematoda. According to the first checklist of parasites of fishes of Iraq (Mhaisen, 1980), the family Capillariidae has no any representative among parasites infecting fishes of Iraq. Later on, Ali et al. (2014) enlisted two genera of this family from freshwater fishes of Basrah province, but in connection with the parasitic fauna of marine fishes of Iraq (Mhaisen et al., 2018), no any member of this family is so far known. 
Parasites cause a great losses in fish aquaculture where they are considered as a mean health problem, therefore the present study aimed to give the full description of $P$. tomentosa from the grass carp which represents its first record from fishes of Iraq.

\section{Materials and Methods}

Nematodes (Figure 1) were collected from the intestine of 110 specimens of grass carps that collected from three fish pond stations in Basrah province during the period from March till July 2007. The first station was the Experimental Aquaculture Station of Marine Science Centre of University of Basrah. The second station was Al-Midaina Pond Station in Al-Midaina Shire and the third station was Faddak Fish Pond Station which is located in Shatt Al-Arab Shire. Nematodes were killed by warm water $\left(60-63{ }^{\circ} \mathrm{C}\right)$ and preserved in alcohol-glycerin. Temporary slides were prepared by using lacto phenol and as semi-permanent slides by using glycerin gel (Garcia \& Ash, 1975). The incidence and intensity of infection was calculated according to Bush et al. (1997). The figures were drawn by using a Camera Lucida (Drawing tube).

\section{Results}

Cultured grass carp was found infected by the nematodes Pseudocapillara tomentosa. Fishes of Faddak Pond Station were the only hosts of such parasites in this study. The infected fishes were fed on aquatic plants as a supplemented food which were brought directly from the natural water bodies. In contrast, fishes of other station didn't feed on such food. Such plants may harboring the infective stages of these parasites. The infection was reported during the period from April till July 2007. Generally, the maximum incidence of infection and the maximum intensity of infection was $26.6 \%$ in April and 8.5 in June, respectively, while, the highest percentage of incidence of infection in Faddak station was $88.8 \%$ in April, then it dropped to $5.8 \%$ during July (Table 1). This nematode was recorded in the last third of the intestinal tract of fish. The nematodes infected the mucosal layer of the intestine and heavy mucus was noticed in the site of infection. The intestine was emaciated in the site of infection. Both sexes of $P$. tomentos $a$ were detected from the infected fishes. The description and measurements of this nematode is given here.

Male: (measurements in millimeter based on 10 specimens). Small nematode, males were shorter and thinner than the female parasites. Length of body 2.0463.239 (2.521) and the width 0.031-0.039 (0.034). Total length of esophagus is 1.192-2.212 (1.591), representing 63\% of body length. Stichosome (ST) consisting of a single row of 25-34 (29) large stichocytes with large nuclei. Esophagus including stichosome 1.068-2.039 (1.553), length of muscular esophagus is 0.106$0.173(0.141)$, Nerve ring (NR) distance from the anterior end (AE) of the body $0.022-0.058(0.038)$. Spicule (S) length is $0.176-0.256(0.194)$ and its wide 0.0066 
at proximal, 0.0047 at middle and 0.0037 at distal end. Spicule surface smooth and with non-spiny spicule sheath. Posterior end (PE) of body rounded.

Female: (measurements in millimeter based on 10 specimens). Length of body 4.029-7.291 (5.2) and the width 0.043-0.063 (0.052). A total length of esophagus 1.659-2.172 (1.962), representing $37.7 \%$ of body length. Eggs oval and contain distinctive bipolar plugs (PP). Size of eggs 0.034-0.036 in length and 0.018-0.024 in width. Eggs wall thickness 0.0007-0.001 (0.00075), polar plugs 0.0014-0.0018 long and 0.006-0.0079 wide.

Table 1: Monthly differences in incidence and intensity of infection in Faddak station.

\begin{tabular}{|l|c|c|c|c|}
\hline \multicolumn{1}{|c|}{ Month } & $\begin{array}{c}\text { Length group } \\
(\mathrm{cm})\end{array}$ & $\begin{array}{c}\text { Number of fishes } \\
\text { examined }\end{array}$ & $\begin{array}{c}\text { Incidence } \\
(\%)\end{array}$ & Intensity \\
\hline April & $12.4-19$ & 9 & 88.8 & 5.1 \\
\hline May & $19.5-23.7$ & 10 & 20 & 14 \\
\hline June & $23.5-26.7$ & 11 & 36.3 & 8.5 \\
\hline July & $23-37$ & 17 & 5.8 & 1 \\
\hline Total & $12.4-37$ & 47 & 31.9 & 6.9 \\
\hline
\end{tabular}

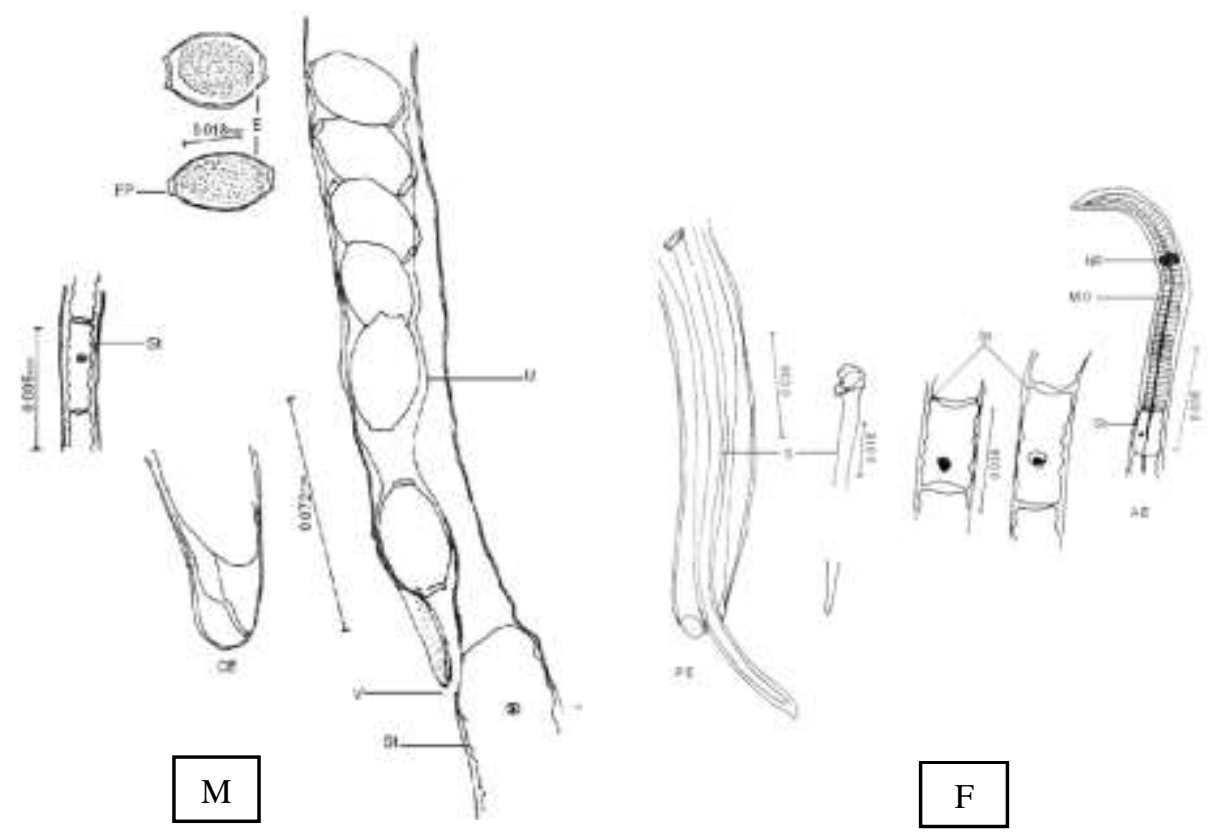

Figure 1: Pseudocapillaria tomentosa ( $\mathrm{F}=$ female, $\mathrm{M}=$ male).

$\mathrm{S}=$ Spicule, $\mathrm{St}=$ Stichosome, $\mathrm{NR}=$ Nerve Ring, $\mathrm{MO}=$ Muscular Oesophagus, $\mathrm{AE}=$ Anterior End, $\mathrm{E}=$ Eggs, $\mathrm{PP}=$ Polar Plug, $\mathrm{St}=$ Stichosome, $\mathrm{U}=$ Uterus, $\mathrm{V}=$ Vulva, $\mathrm{CE}=$ Caudal End, $\mathrm{PE}=$ Posterior End. 


\section{Discussion}

Yamaguti (1961) considered that there is one genus (Capillaria Zeder, 1800) within the family Capillaridae. Moravec (1982) created a new system for capillariid nematodes, based on revaluation of the features used in the taxonomy of these nematodes and divided the capillariids into 16 genera.

Al-Daraji (1986) recorded Capillaria sp. from intestine of Mesopotamichthys sharpeyi (reported as Barbus sharpeyi). Abdul-Ameer (1989) recorded Capillaria sp. in liver of Cyprinion macrostomum. These were the only two studies that are related to Capillariidae from fishes of Iraq, therefore reporting P. tomentosa of the present investigation is considered as the first record in Iraq. Without having the male, these nematodes cannot be identified to the generic rank, because the morphology of most female capillariids is rather uniform (Moravec et al., 1999). Large numbers of male and female parasite specimens gave enough ability to classify, measurements and specification for this species which are coincided with the study of Moravec et al. (1999) about infection of ornamental fish Barbus tetrazona (synonym of Puntigrus tetrazona) by this parasite, study of Kent et al. (2002) about infection of zebrafish, and Bykhovskaya-Pavlovskaya et al. (1964) about this species (under its synonym Capillaria leucisci).

The life cycle of $P$. tomentosa is probably direct, without an intermediate host, but freshwater oligochaetes may play a role as paratenic hosts (Moravec, 1999). For preventing the infection with this parasite, there are some studies, for example, Kent et al. (2019) exposed parasite eggs to elevated temperatures $\left(40{ }^{\circ} \mathrm{C}, 45^{\circ} \mathrm{C}\right.$ and $50{ }^{\circ} \mathrm{C}$ ) for 1,8 , or $24 \mathrm{~h}$, which resulted in substantial reduction in viability of such eggs. Also, UV radiation was effective at $50-300 \mathrm{mWs} / \mathrm{cm}^{2}$ and $<2 \%$ at 20 $\mathrm{mWs} / \mathrm{cm}^{2}$, while three chlorine products (JT Baker, Clorox ${ }^{\circledR}$ and Bi-Mart) were tested at $25,50,100,500$ and $3,000 \mathrm{ppm}(\mathrm{pH} 7.0-7.3)$ with 10 minutes exposure and found all were effective at 500 or $1,000 \mathrm{ppm}$.

\section{References}

Abdul-Ameer, K.N. (1989). Study of the parasites of freshwater fishes from Tigris River in Salah Al-Dien Province, Iraq. M. Sc. Thesis, Coll. Sci., Univ. Baghdad: 98 pp. (In Arabic).

Al-Daraji, S.A.M. (1986). Survey of parasites from five species of fishes found in Al-Hammar Marsh. M. Sc. Thesis, Coll. Agric., Univ. Basrah: 130 pp. (In Arabic).

Ali, A.H.; Mhaisen, F.T. \& Khamees, N.R. (2014). Checklists of nematodes of freshwater and marine fishes of Basrah Province, Iraq. Mesopot. J. Mar. Sci., 29(2): 71-96.

Bush, A.O.; Lafferty, K.D.; Lotz, J.M. \& Shostak, A.W. (1997). Parasitology meets ecology on its own terms. J. Parasitol., 83(4): 575-583.

Bykhovskaya-Pavlovskaya, I.E.; Gusev, A.V.; Dubinia, M.N.; Izyumova, N.A.; Smirnova, T.S.; Sokolovskaya, I.L.; Shtein, G.A.; Shul'man, S.S. \& Epshtein, V.M. (1964). Key to parasites of freshwater fish of the U.S.S.R. Akad. Nauk S.S.S.R., Moscow: 727 pp. (In Russian). 
Garcia, L.S \& Ash, L.R. (1975). Diagnostic parasitology: Clinical laboratory manual. C.V. Mosby Co., St. Louis: 112 pp.

GBIF (2021). Global Biodiversity Information Facility, on-line database, http:// www.gbif.org. (Accessed 10 November 2021).

Kent, M.L.; Watral, V.; Villegas, E.N. \& Gaulke, C.A. (2019). Viability of Pseudocapillaria tomentosa eggs exposed to heat, ultraviolet light, chlorine, iodine, and desiccation. Zebrafish, 16(5): 460-468. DOI:10.1089/zeb. 2019.1736.

Kent, M.L.; Spitsbergen, J.M.; Matthews, J.M.; Fournie, J.W.; Murray, K.N. \& Westerfield, M. (2002). Diseases of zebrafish in research facilities. Zebrafish Int. Resour. Cent. http://www.ZIRC.com.

Mhaisen, F.T. (1980). Fish parasitology in Iraq. Basrah Nat. Hist. Mus., Publ. No. 3: 36 pp. + IX pls.

Mhaisen, F.T.; Ali, A.H. \& Khamees, N.R. (2018). Marine fish parasitology of Iraq: A review and checklists. Biol. Appl. Environ. Res., 2(2): 231-297.

Moravec, F. (1982). Proposal of a new systematic arrangement of nematodes of the family Capillariidae. Fol. Parasitol., 29(2): 119-132.

Moravec, F. (1987). Revision of capillariid nematodes (Subfamily Capillariinae) parasitic in fishes. Acad. Natkadatelstiv Ceskoslov. Akad. ved, Praha: 141 pp.

Moravec, F.; Wolter, J. \& Körting, W. (1999). Some nematodes and acanthocephalans from exotic ornamental freshwater fishes imported into Germany. Fol. Parasitol., 46(4): 296-310. PMID: 10730202.

WoRMS (2021). World Register of Marine Species at http://www.marinespecies. org at VLIZ. (Accessed 10 November 2021).

Yamaguti, S. (1961). Systema helminthum, vol. III: The nematodes of vertebrates, part I \& II. Intersci. Publ., New York: 1261 pp. 